\title{
Sackings leave gene database floundering
}

Laura Bonetta

Just a decade ago, it was at the cutting edge of bioinformatics. But today, the Genome Database (GDB) — which is supposed to be the main international repository for genome mapping information - cuts a sad figure.

The Hospital for Sick Children (HSC) in Toronto, Canada, which hosts the database, has fired the GDB's director, Jamie Cuticchia, and another official, Gregg Silk, alleging that they illegally transferred the GDB's Internet domain name to a Maryland-based non-profit company. Cuticchia argues that the transfer was part of a legitimate effort to raise funds.

The GDB was established at Johns Hopkins University in Baltimore, Maryland, in 1990, with funding from government agencies including the US Department of Energy and the National Institutes of Health. The GDB's mission, according to its website, is "to make available to scientists an encyclo- pedia of the human genome that is being constantly revised and updated".

Cuticchia moved the database from Johns Hopkins to Toronto in 1998 after the US Department of Energy, then the primary funder, cut off support for the project. Cuticchia has raised about Can $\$ 700,000$ (US\$441,000) a year in funding to run the GDB, but the database has struggled to maintain itself as a useful resource. It has not incorporated sequence data to supplement its maps, for instance, and its software tools need upgrading.

"GDB was trying to change its approach and get up to date," says Ewan Birney of the European Bioinformatics Institute in Hinxton, near Cambridge.

The latest moves have thrown the GDB's future into question. Cuticchia maintains that he discussed with HSC officials his plans to redevelop the GDB by selling licences to companies allowing them to run a copy of the database. Cuticchia says

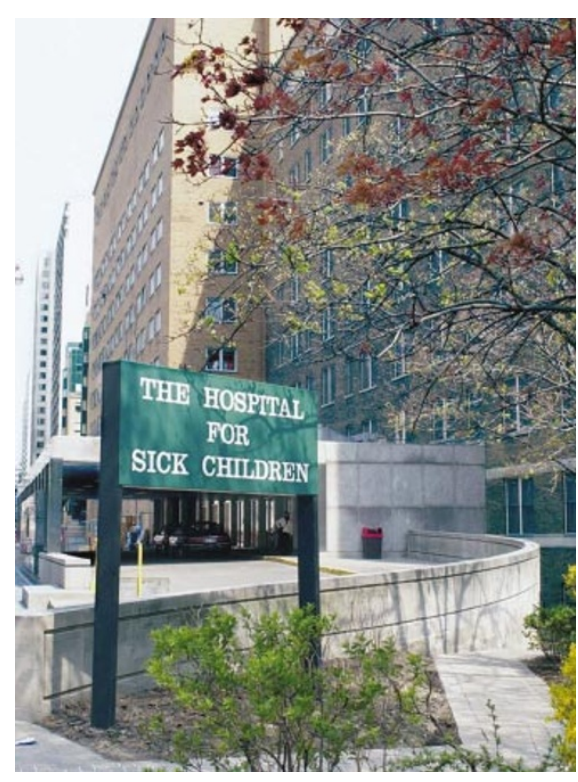

A row has erupted over the Genome Database at the Hospital for Sick Children in Toronto.

\section{Funding fears spark Italian protests}

\section{Alison Abbott}

One hundred and fifty scientists from Milan took part last week in a symbolic funeral complete with coffin, musicians and black balloons - for Italian research.

The mock funeral was part of a wave of protests, including strikes and demonstrations, that took place across the country, as scientists expressed their fear that Prime Minister Silvio Berlusconi's right-wing government will reduce support for basic research.

Since taking office in July, Berlusconi's government has unsettled scientists by hinting that it favours applied research. Now rumours that budgets will be cut are being confirmed. And in an unprecedented move, the government last week rejected the three-

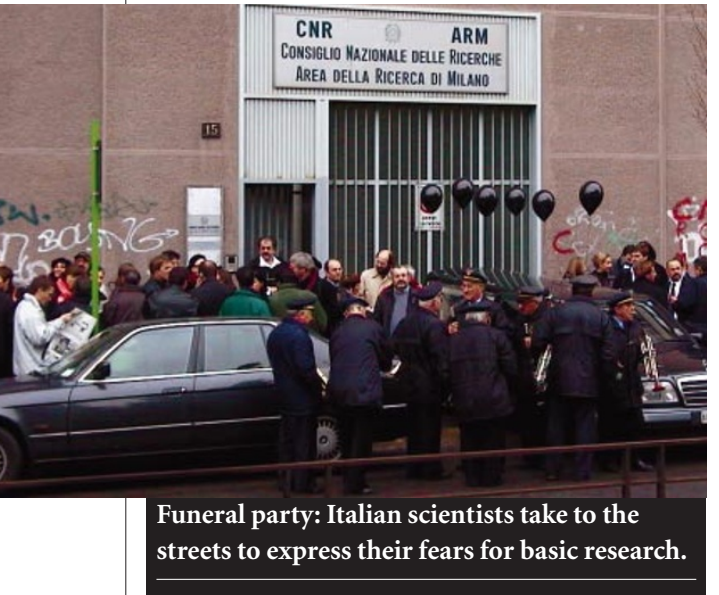

year plan of the National Research Council (CNR), which had proposed an expansion of staff. Scientists fear that reforms introduced by the previous government to make Italian research more efficient are now under serious threat (see Nature 412, 264-265; 2001).

When public expenditure plans for 2002 are approved towards the end of the year, staffing is expected to be frozen and budget cuts are in store. Sources in the education and research ministry say that spending is likely to be kept at 2001 levels, effectively cutting research budgets by the annual rate of inflation, now running at $2.9 \%$.

Scientists who helped prepare the CNR's three-year plan are dispirited. In the past two years, the agency has reorganized its 330 units into 100 larger institutes. To make this system work efficiently, it planned to increase its staff by 1,750 , or $30 \%$, and its budget by $90 \%$, over three years. Elisabetta Visalberghi, research director of the CNR Institute for Psychology in Rome, says the expansion is important to ensure that there are replacements for the generation of baby boomers who are now reaching retirement.

University reforms are also under pressure. Italian universities are changing from a system of five-year undergraduate degrees to three-year bachelor programmes plus optional two-year masters degrees. The changes will involve an additional teaching load, for which the government does not want to provide extra money. that the hospital decided not to be involved and told him that he was free to seek investors. Cuticchia says that the transfer of the GDB's domain name, to a company called GDB Human Genome Database, was a step in his plan to raise funds to update the database's software and continue providing academics with free access.

On 18 October, Cuticchia says that he and Silk, who was director of planning and operations of the HSC's bioinformatics centre, told hospital management that they had secured funding for the redevelopment of the GDB. The following day, the pair were suspended and on 2 November they were fired.

But HSC spokeswoman Cyndy DeGiusti says that the hospital only found out about Cuticchia's efforts to commercialize the database "by accident". The hospital has filed a 'notice of action' - the first step towards a lawsuit - to recover the domain name. "We caught it early enough so that the actual value of what was taken was not high, but it was proceeding down the road of taking valuable assets," says DeGiusti.

Cuticchia has been barred from his lab while the hospital conducts an audit. HSC geneticist Lap-Chee Tsui, co-discoverer of the cystic fibrosis gene, will for the time being oversee the GDB.

Although his appointment at the University of Toronto - with which the HSC is affiliated - has not been affected, Cuticchia says he is forbidden to contact his students. "The hospital has set a precedent by saying 'We can take your grants, equipment and students," claims Cuticchia. "It is a black day for academic freedom."

www.gdb.org 